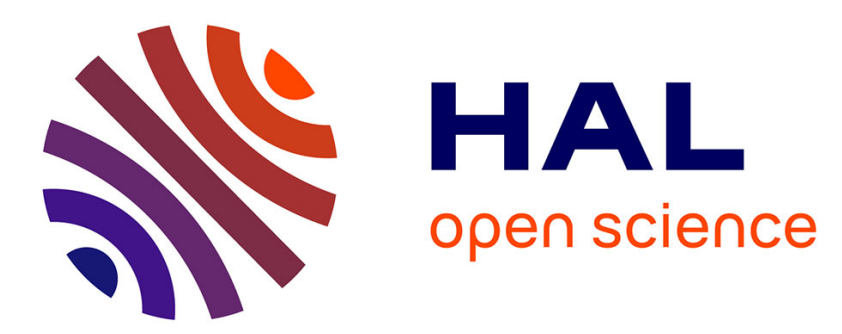

\title{
The formation of the West European Rift; a new model as exemplified by the Massif Central area \\ Olivier Merle, Laurent Michon
}

\section{To cite this version:}

Olivier Merle, Laurent Michon. The formation of the West European Rift; a new model as exemplified by the Massif Central area. Bulletin de la Société Géologique de France, 2001, 172 (2), pp.213 - 221. 10.2113/172.2.213 . hal-01391920

\section{HAL Id: hal-01391920 \\ https://hal.univ-reunion.fr/hal-01391920}

Submitted on 4 Nov 2016

HAL is a multi-disciplinary open access archive for the deposit and dissemination of scientific research documents, whether they are published or not. The documents may come from teaching and research institutions in France or abroad, or from public or private research centers.
L'archive ouverte pluridisciplinaire HAL, est destinée au dépôt et à la diffusion de documents scientifiques de niveau recherche, publiés ou non, émanant des établissements d'enseignement et de recherche français ou étrangers, des laboratoires publics ou privés. 


\title{
The formation of the West European rift : A new model as exemplified by the Massif Central area
}

\author{
Olivier MERLE ${ }^{1}$ and LALRENT MICHON ${ }^{1}$
}

Key words. - Massif Central, Alps, West European Rift. Tectonic. Volcanism. Cenozoic.

Abstract. - In this paper, we use mainly field data from the Massif Central area, which have been presented in a companion paper [Michon and Merle, 2001], to discuss the origin and the cvolution of the West European Rift system. It is shown that the tectonic event in the Tertiary is two-stage. The overall geological evolution reveal a tectonic paradoxc as the first stage strongly suggests passive rifting, whereas the second stage displays the first stage of active rifting. In the north, crustal thinning, graben formation and sedimentation at sea level without volcanism during the Lower Oligocene, followed by scattered volcanism in a thinned area during Upper Oligocene and Lower Miocene, represent the classical evolution of a rift resulting from extensional stresses within the lithosphere (i.c. passive rifting). In the south, thimning of the lithospheric mantle associated with doming and volcanism in the Upper Miocene, together with the lack of crustal thinning, may be easily interpreted in terms of the first stage of active rifting due to the ascent of a mantle plume. This active rifting process would have been inhibited before stretching of the crust, as asthenospheric rise associated with uplift and volcanism are the only tectonic events observed. The diachronism of these two events is emphasized by two clearly distinct orientations of crustal thinning in the north and mantle lithospheric thinning in the south. To understand this tectonic paradox, a new model is discussed taking into account the Tertiary evolution of the Alpine chain. It is shown that the formation of a deep lithospheric root may have important mechanical consequences on the adjacent lithosphere. The downward gravitational force acting on the descending slab may induce coeval extension in the surrounding lithosphere. This could trigger graben formation and laguno-marine sedimentation at sea level followed by volcanism as expected for passive rifting. Concurrently, the descending lithospheric flow induces a flow pattern in the asthenosphere which can bring up hot mantle to the base of the adjacent lithosphere. Slow thermal erosion of the base of the lithosphere may lead to a late-stage volcanism and uplift as expected for active rifting.

\section{La formation du rift Ouest-européen : un nouveau modèle tectonique}

\author{
Mots-clès. - Massif Central. Alpes. Rift Ouest-européen. Tectonique. Volcanisme. Céno\%oïque.
}

Résumé. - La synthèse des données géologique montre une évolution tout à fait différente cntre le nord et le sud du Massif central. Le nord du Massif central est principalement caractérisé à l'Oligocène par un fort amincisscment crustal, la formation de fossé d'effondrement au niveau de la mer avec une sédimentation épaisse (jusqu’à $3000 \mathrm{~m}$ ) sans volcanisme, suivie de la fin de l'Oligocène supérieur au Miocène inférieur d'un volcanisme localisé dans les zones de plus fort amincissement crustal. Cettc évolution est typique d'un rift de type passif. ^u sud, l'évolution tectonique est caractérisée au Miocène supérieur par un très fort amincissement de la lithosphère mantellique sans amincissement crustal, un soulèvement et une importante phase magmatique. Cette évolution est cohérente avec celle attendue lors des premiers stades d'un rift de type actif. Le diachronisme de ces deux événements est souligné par l'orientation N-S de l'amincissement crustal au nord et l'orientation N135'E de l'amincissement de la lithosphère mantellique au sud. Le modèle proposé pour expliquer ce paradoxe part de l'hypothèse que cette évolution procède d'une cause unique. qui se trouve dans la formation de la chaine alpine immédiatement plus à l'est. La chaine alpine est spatialement et temporellement connectée au Rift Ouest-européen. Celui-ci comprend, d'cst en ouest, le graben de l'Eger, le graben du Rhin et les fossés d'effondrement du Massif central. l'ensemble du système de grabens étant disposés concentriquement autour du front alpin. La déformation dans les Alpes démarre à l'Eocène comme en témoigne les données géochronologiques récentes sur le métamorphisme de haute pression dans les zoncs les plus internes de la chaîne. La progression vers l'ouest des déformations est attestée par les données stratigraphiques qui montrent que le chevauchement du Briançonnais sur la zone dauphinoise date du début de l'Oligocène. La formation de ce chevauchement crustal majeur de la chaine alpine est ainsi contemporaine de la formation des grabens et de la sédimentation dans le Massif central.

Deux questions se posent : la formation d’une chaîne de montagne peut-elle générer dans la lithosphère adjacente un épisode d'extension? les modalités de cette extension peuvent-elles se dérouler en deux étapes successives, la première ayant les caractéristiques d'un rift passif et la seconde les caractéristiques d'un rift actif'? Pendant la collision continentale, le découplage de la croûte et du manteau entraînc la formation d’unc profonde racine constituéc de manteau lithosphérique. Des simulations numériques ont montré que la force gravitaire de cette racine lourde, plus dense que l'asthénosphère environnante, engendrait une compression dans la croûte sus-jacente et de l'extension dans la croûtc adjacente. Un tel système est à même de dépasser la résistance en extension de la lithosphère adjacente et de provoquer un épisode de rifting qui présentera les caractéristiques d'un rift de type passif. La création de la racine li- 
thosphérique s'accompagne également d’un autre processus. Lorsque la racine lithosphérique se forme, elle prend la place de l'asthénosphère et provoque son déplacement latéral. Ceci induit un flux asthénosphérique, ascendant au niveau de la lithosphère adjacente, qui contrebalance le mouvement descendant lié à la racine. La cellule ainsi crééc amène de l'asthénosphère chaude à la base de la lithosphère adjacente. Si le processus connaît une ampleur suffisante, pendant une durée de temps de plusieurs millions d’années, une érosion thermique de la base de la lithosphère adjacente se produit, conduisant à un soulèvement isostatique et une phase de volcanisme, d'une manière tout à fait semblable à ce qui est observé dans le cas d'un rift actif. La création de la racine lithosphérique d'une chaîne de montagne peut produire ainsi deux effets dans la lithosphère adjacente : une extension lithosphérique et une érosion thermique à la base de la lithosphère. Ces deux effets ne sont pas synchrones et le second est différé dans le temps. Dès que la racine lithosphérique commence à se former, la force verticale agissant sur cettc racine peut engendrer l'extension dans la lithosphère adjacente. En revanche, l’érosion thermique est un phénomène tardif qui nécessite (i) que la racine atteigne une certaine profondeur pour engendrer un flux asthénosphérique conséquent et (ii) un temps relativement long pour réaliser une érosion thermique significative. Le paradoxe tectonique enregistré dans le Massif central peut être résolu en considérant la formation de la profonde racine alpine. D'une façon tout à fait semblable à l'évolution en deux temps découlant du modèle proposé, le Massif central est d’abord affecté par un rifting de type passif suivi quelques millions d’années plus tard par les premiers stades d'un rift de type actif.

\section{INTRODUCTION}

The formation of the West European rift remains a subject of great debate. As a continental rift, its origin may be attributed to two different tectonic processes. The first hypothesis involves continental rifting, which would be entirely governed by lithosphere extension. Such rifts, which are termed passive rifts, result from extensional failure of the continental lithosphere, where the main cause is to be found in far-field stresses generated at plate boundaries. The second hypothesis refers to a continental rift initiated above a mantle plume or diapir. This second type, usually termed active rifting, is associated with thermal thinning of the base of the lithosphere due to heat advection at the lithosphere-asthenosphere boundary (LAB).

The initial stages of these two different types of rift are thought to be significantly different, which allows distinction in the field [Park, 1988]. Plume-generated rifts are associated with crustal doming and abundant volcanism in their initial stages. Graben formation and sedimentation occurs later, when the doming reaches a critical level to initiate extensional faulting within the crust. In contrast, far-field stress-generated rifts start with graben formation and sedimentation close to sea level and develop doming and volcanism at a later stage.

In this paper, we use mainly field data from the Massif central area, which have been presented in a companion paper [Michon and Merle, 2001], to discuss the origin and the evolution of the West European Rift system. As exemplified by the evolution of the Massif Central rift, we show that this extension is closely related to the formation of the Alps. A new tectonic model is proposed which takes into account the role of the deep lithospheric root created during mountain building processes in the deformation of the surrounding lithosphere.

\section{THE TECTONIC PARADOX OF THE MASSIF CENTRAI.}

In this study, we do not deal with the very sparse volcanic manifestations which occurred in the Paleocene at around 60-65 Ma [Vincent et al., 1977]. We believe that this rare pre-rift volcanism may be attributed to the flexure of the lithosphere associated with the first compressions recorded in the Alps [see the discussion in Michon and Merle, 2001], as testified by the oldest radiometric data at about $65 \mathrm{Ma}$ in the Sesia Austro-Alpine unit [Froitzheim et al., 1996; Rubatto et al., 1999] and geophysical data about the buckling of the French lithosphere during the Paleocene [i.e. Lefort and Agarwal, 1996].

Synthesis of the main geological data reveals a strikingly different structural evolution between the northern and the southern parts of the Massif Central. It is useful to summarize these differences as they reveal the fundamental constraints that must be taken into account before proposing a general tectonic model.

The northern part of the Massif Central is characterized by the following structural features:

1) grabens are well developed and display a clear north-south orientation. Sedimentation rates have been high with up to $3500 \mathrm{~m}$ in the Limagne graben;

2) upper Eocene and Oligocene sedimentation occurred close to sea level, as demonstrated by repeated marine incursions [Giraud, 1902; Gorin, 1974; Chauve et al., 1980; Rat, 1984; Briot and Poidevin, 1998; Bodergat et al., 1999];

3) crustal thimning is locally important, up to $25 \%$ in the Limagne graben [Merle et cl., 1998]. It is spatially connected with the main grabens, and is especially visible below the Limagne and the Bresse grabens [e.g. Bergerat et al., 1990; Truffert et al., 1990; Zeyen et al., 1997];

4) there is a linear relationship between the thickness of Oligocene sediments in the grabens and the amount of crustal thimning, showing that crustal thinning took place in the Oligocene and was achieved when the sedimentation stopped [Fig. 6 in Merle et al., 1998];

5) the sedimentation period lacked accompanying volcanism. Volcanism started by the end of the sedimentation and was mainly developed in the lower Miocene;

6) this scattered volcanism occurred in the west, especially in the Limagne graben, that is in the zone of highest crustal thinning [Fig. 2 in Michon and Merle, 2001];

7) a second magmatic event started after a gap of about $6 \mathrm{Ma}$ in the upper Miocene. This second magmatic event is also restricted to the west, but mainly occurred in an area where geophysical data have revealed no crustal thinning [Zeyen et al., 1997] (e.g. The Chaine des Puys, The Mont Dore, The Sioule, etc). It is coeval with regional doming [Michon and Merle, 2001]. 
The southern part of the Massif Central is characterized by the following structural features

1) basins are not preferentially oriented or bounded by a N $135^{\circ} \mathrm{E}$ oriented horst zone. Upper Eocene-Oligocene sedimentation is never as thick as in the north, with a maximum thickness of a few hundred meters;

2) sedimentation mainly occurred at sea level [Dangeard, 1933; Rey, 1973; Turland el al., 1994].

3 ) the Moho is that-lying at a depth of about $28 \mathrm{~km}$ [Zeyen el al., 1997]. According to the average elevation at about $1000 \mathrm{~m}$ of the Variscan basement, the crust is about $29 \mathrm{~km}$ thick and crustal thinning is considered to be negligible;

4) the lithospheric mantle is strongly thinned, up to $65 \%$, along a direction which is nearly perpendicular to the orientation of crustal thinning recorded in the north [Granet el al., 1995 a and b; Sobolev el al., 1996] [Fig. 3 in Michon and Merle, 2001];

5) volcanism started in the upper Miocene more than 10 Ma after the end of the main phase of sedimentation [Michon and Merle, 2001]. It is associated with huge volumes of magma and is undisputably the major volcanic phase in the Massif Central;

6) doming of the area is shown to be coeval with this major magmatic event [e.g. Le Griel, 1988: Goür de Herve and Etienne, 1991: Defive and Cantagrel, 1998]

When comparing the north and the south of the Massif Central, these data reveal a tectonic paradox. The Oligocene and lower Miocene history in the north of the Massif Central presents all the characteristics of passive rifting whereas the upper Miocene to present-day history in the south strongly suggests active rifting (fig. I).

In the north, crustal thinning, graben formation and sedimentation at sea level without volcanism during the Lower Oligocene, followed by scattered volcanism in a thinned area during Upper Oligocene and Lower Miocene, represent the classical evolution of a rift resulting from extensional stresses within the lithosphere.

In the south, thinning of the lithospheric mantle associated with doming and volcanism in the Upper Miocene, together with the lack of crustal thinning, may be easily interpreted in terms of the first stage of active rifting due to the ascent of a mantle plume. This active rifting process would have been inhibited before stretching of the crust, as asthenospheric rise associated with uplift and volcanism are the only tectonic events observed. The diachronism of these two events is emphasized by two clearly distinct orientations of crustal thinning in the north and mantle lithospheric thinning in the south.

The negligible crustal thinning in the south explains well the lack of volcanism following the Upper EoceneOligocene sedimentation period. This merely indicates that the Oligocene passive rifting event recorded in the north has weakly affected the south, and that the lithospheric stretching was not strong enough at that time to induce partial melting in the mantle. In the same way, the late second magmatic event is recorded in the north in a non-thinned crustal area, after an interruption of volcanism for several millions years. This suggests that the southern active rifting phase has propagated to the north in the very late Tertiary.

According to this interpretation, we face the following dilemna. It could be considered that these two rifting events result from two different processes which are completely unrelated. However, two superimposed unrelated rifting events in the Tertiary would be a surprising coincidence, all the more because the same tectonic evolution is recorded far away from the Massif Central area in the Eger graben of the Czech Republic [Michon and Merle, 2001]. Another alternative would be to consider that the whole Tertiary history of the Massif Central area and the Eger graben result firom a single cause at the scale of western Europe. We discuss this hypothesis in the following section.

\section{THE ALPS AS A SINGLE CAUSE}

Several models have been proposed to explain the formation of the West European rift [e.g. Bergerat, 1985; Bles et al., 1989; Ziegler, 1992; Lacombe el al., 1993]. Among them, the compression associated with the late stages of the Pyrenean orogeny has been advocated as a source for far-field stresses capable of reactivating the Permo-Carboniferous fracture systems. In such an hypothesis, the formation of the Eger graben in the Bohemian Massif (fig. 2), far away from the Pyrenees, which reveals a tectonic evolution surprisingly similar to that of the Massif Central [Michon and Merle, 2001], is poorly understood.

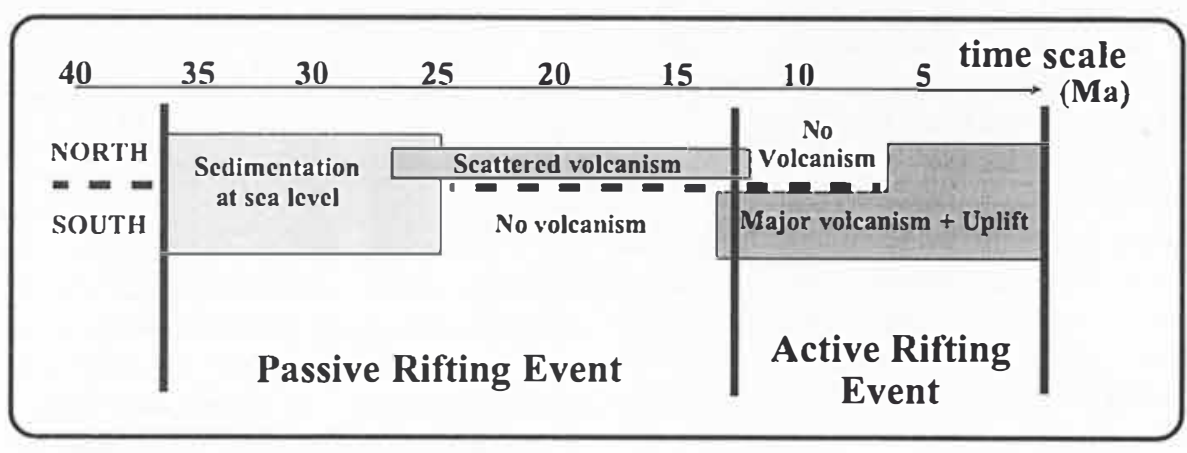

Fici. 1. - Summary of main geological data that allow us to propose a two-lold evolution of the rifting process during the Tertiary. Sedimentation at sea level followed by scattered voleanism lits with a passive rilting event, whereas the major phase of voleanism associated with uplifi lits with an actie rifling event (explanation in the text)

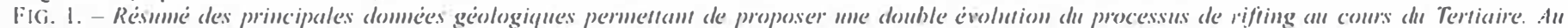

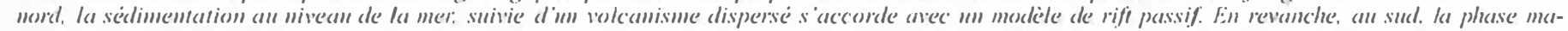

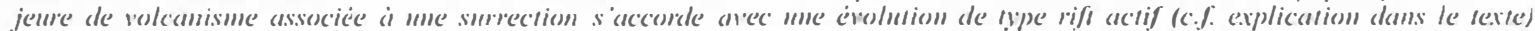




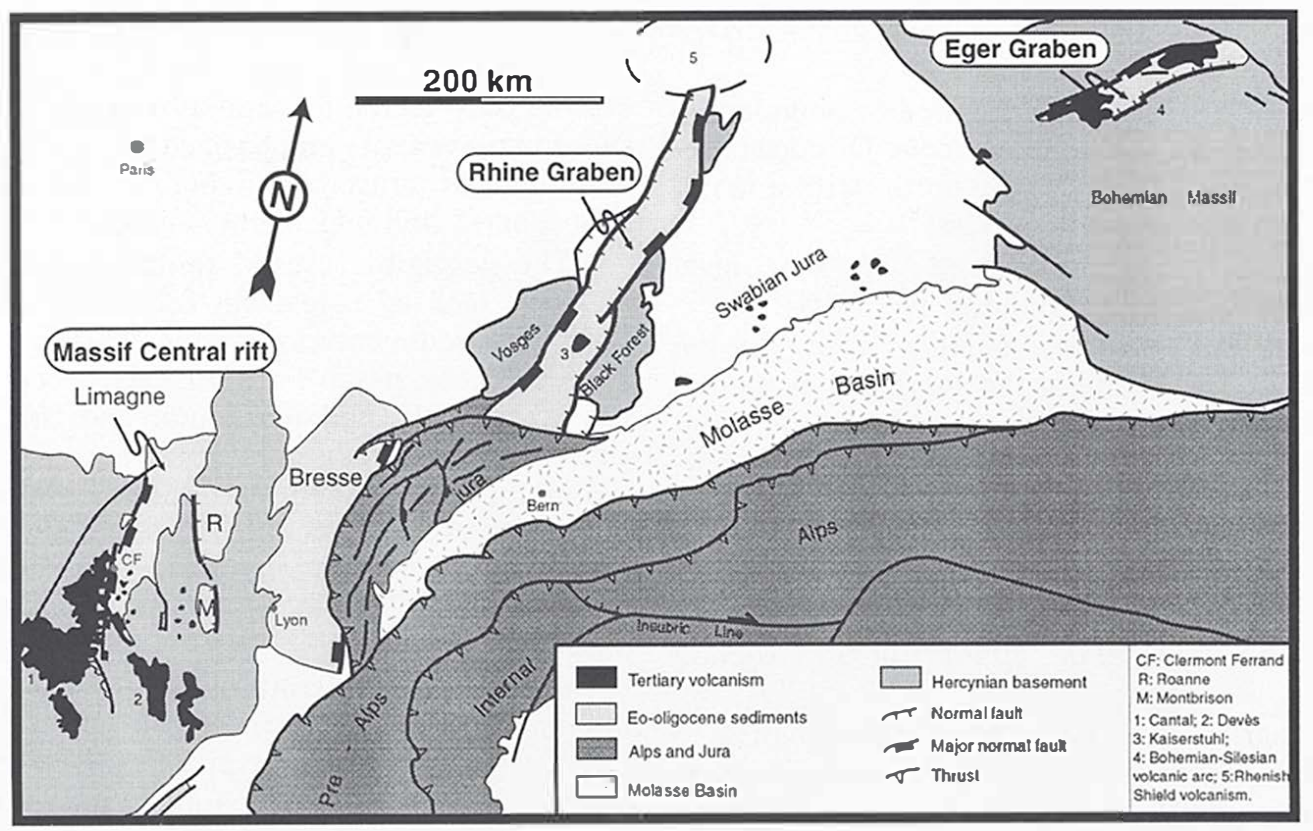

FIG. 2. - Simplified geological map showing the close spatial relationship between the Alps and the West European Rift system. Most structural features of the rifts, including the Massif Central area, the Rhinegraben, the Swabian Jura and the Eger Graben are coneentric around the Alpine chain. FIG. 2. - Carte géologique simplifie montrant l'érovite relation spatiale entre les slpes et le rifi Ouest-européen. Les principantx segments du rifi (le Massif central. le graben du Rhin. le .hura sourabe et le graben de l Eger) sont disposes concentriquement antour de la chaine alpine.

In a search of a single cause at the scale of plate tectonics which can explain not only the Oligocene rifting but also the following asthenospheric rise and related magmatism, it is clear that the Alps should be considered as the best candidate because this mountain chain is temporally and spatially connected with the entire West European Rift system (fig. 2).

The West European Rift system displays a series of grabens or volcanic manifestations which roughly surround the Alpine chain. From east to west, these include the Eger graben, the Swabian Jura, the Rhine graben and the Massif Central (fig. 2). To the south of the Massif Central, the present-day structure of grabens and the volcanism are related to the opening of a marginal basin during the counterclockwise rotation of the Corso-Sardinia micro-plate [Channell and Mareschal, 1989; Carminati el al., 1998; Seranne, 1999], an event which overprinted the earlier sedimentary basins due to the West European rift striclo sensu. This rifting event results from a completely different plate kinematic history than that of the West European Rift system and is best referred to as the North-West Mediterranean Rift [Seranne and Merle, 1999].

In the West European Rift system, incipient basins can be dated from the Priabonian (late Eocene) as this period corresponds to the beginning of the sedimentation in the Massif Central, the Rhine graben and the Eger graben. The major episode of graben formation occurred during the Oligocene. Deposition lasted until the end of the Oligocene. In a few areas, some residual basins of small extent reveal ongoing sedimentation during the Aquitanian [Gerbe el al., 1998; Hugueney el al., 1999].

The beginning of the major phase of deformation in the Alps can be dated fiom stratigraphic records. During the Eocene, a large paleogeographical domain including the
Briançonnais and the sub-Briançonnais zones of the Alps corresponded to a zone of widespread deep marine sedimentation [e.g. Kerchove, 1980]. This so-called Nummulitic sedimentation ended in the late Eocene with olistostrome formations, immediately followed by nappe emplacement. Most olistostromes in the sub-Briançonnais and Briançonnais zones can be dated from the Priabonian [e.g. Kerckhove, 1969: Bravard el al., 1981; Kerckhove and Pairis, 1986; Barféty el al., 1992].

The formation of the Frontal Penninic thrust is usually considered to occur at the beginning of the Oligocene [Tricart, 1986]. According to this major event, a sedimentation of "Red Molasse» took place in the Dauphinois zone during the Oligocene [Kerckhove, 1980]. These molassic sediments result from the erosion of the high relief formed at that time in the internal domain.

Geochronological records are still a matter of controversy in the Alps. Recent data seem to indicate that HP metamorphism in the most internal zones, with the exception of the Austro-Alpine Sezia zone, occurred in the range from 50 to $30 \mathrm{Ma}$ [e.g. Monié and Philippot, 1989; Tilton el al., 1991; Bowtel el al., 1994; Duchêne el al., 1997, Rubatto el al., 1998]. Despite the uncertainties linked to geochronological methods, these ages from the most internal zones, together with the migration of crustal deformation fiom east to west, fit quite well with the lateEocene/early Oligocene deformation recorded at the boundary between the internal and the external domain (i.e. Frontal Penninic thrust). From these data, it can be concluded that the major deformation in the Alps started in the middle Eocene in the most internal units and reached the boundary with the external domain in the end of the Priabonian or the beginning of the Rupelian. 
The beginning of crustal thinning and graben formation recorded in the north of the Massif Central and the Rhine graben appears to be coeval with crustal thickening and major crustal wedge overthrusting in the western Alps. What must be explained is the juxtaposition of two lithospheric domains, which exhibit at the same time extension and compression. The questions are the following : can the formation of a mountain chain generate extension in the surrounding lithosphere? Can the deformation in the surrounding lithosphere be two-phase and mimic first a passive rifting and then an active rifting?

\section{THE ROLE OF THE LITHOSPHERIC ROOT}

To answer these questions, the deformation associated with the collision of two lithospheric plates must be considered in its entirety. In most mountain chains, the deformation in the crust and the mantle lithosphere is decoupled along a major shear zone located at the interface between the lower crust and the mantle. Such a process, which was first proposed for the Himalayan chain [Mattauer, 1986], leads to the formation of both an upper stack of crustal wedges and a lower mantle lithospheric root. The depth of this lithospheric root is linked to the amount of shortening following the continental collision.

The formation of a mantle lithospheric root has important mechanical consequences. It has been known for a long time that the mantle lithosphere is denser that the asthenosphere. This difference in densities is the key parameter which explains the sinking of oceanic lithosphere in subduction zones. It is responsible for the downward body force usually referred to as the trench pull [e.g. Turcotte and Schubert, 1982].

In the same way, the mantle root in continental collision is denser than the surrounding asthenosphere. It follows that this slab exerts on the whole collisional system a downward gravitational body force. This downward body force is usually considered as sufficient to maintain the convergent belt in a state of compression even after convergence has ceased [Fleitout and Froidevaux, 1982].

Numerical simulations have been conducted to study the effect and the deformation associated with this major vertical body force [e.g. Fleitout, 1984; Channell and Mareschal, 1989]. It has been shown that a mantle lithospheric root is pulled down into the asthenosphere generating a zone of crustal compression flanked by zones of crustal extension. These numerical models explain the compression in the collision zone and contemporaneous extension in adjacent areas [Mc Kenzie, 1978; Fleitout and Froidevaux, 1982; Channell and Mareschal, 1989]. Significant extensional deformation may be expected as the extensional strength of the lithosphere as a whole is considerably less than its compressive strength [Kusznir and Park, 1986]. The extension should occurr in a way similar to that expected for passive rifting.

As an interesting result of the numerical simulation, the deformation in the adjacent lithosphere is dependant of the asymmetry of the lithospheric thickening [Channell and Mareschal, 1989]. Asymmetric lithospheric thickening leads to enhanced extension in the adjacent lithosphere but on one flank only of the collision zone, the other flank beeing almost devoided of extensional stresses (fig. 3 ).

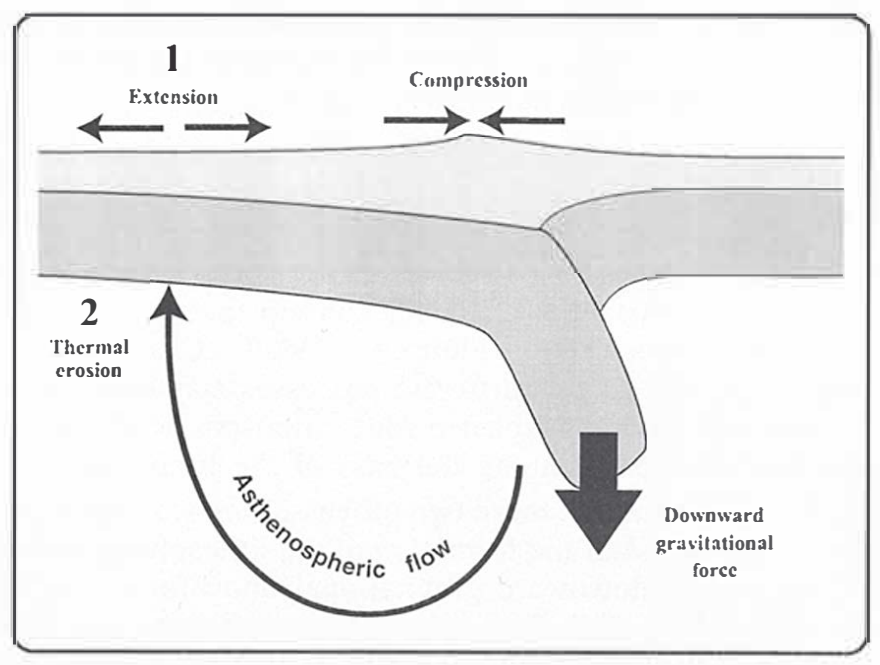

Fici. 3. - Schematic representation of the role of the lithospheric root in triggering rifting in the adjacent lithosphere [after Channel and Mareschal, 1989]. The downward gravitational foree of the dense root induces extension (1) in the adjacent lithosphere and is responsible for a deformation event which resembles passive rifting. The mantle tlow due to the sinking of the root brings hot asthenosphere to the base of the adjacent lithosphere. This induces thermal erosion (2) leading to a deformation event which resembles active rifting (2).

Fici. 3. - Represisentation scheimatique du risle de la racine lithospheriegue

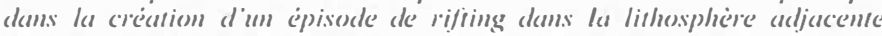
[d'après Channel and Mareschal. 1989]. La force graviraire de la racine

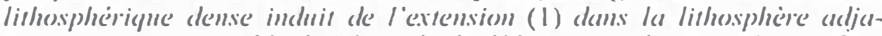
cente et est responsable de lépisode de déformation de type rifi passif. le

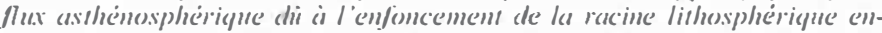
traine du materiel mantelliegue chand a la base de la lishosphiere adjacente. Ceci induit une èrosion thermique (2) et un épisode de déformation de type rifi actif (2).

\section{THE ASTHENOSPHERIC FIOW}

Another process follows from the formation of the mantle lithospheric root. Its consequence on adjacent lithosphere has not been fully studied yet but is clearly apparent in numerical simulations. When sinking into the asthenosphere, the mantle lithospheric root replaces the asthenosphere and expells it away from the root. This induces an asthenospheric flow.

The general flow pattern from numerical modelling clearly shows that downward movement of the mantle lithospheric root is counterbalanced by upward motion of the asthenosphere below the adjacent lithosphere [Channell and Mareschal, 1989] (fig. 3). Considering that the lithosphere is sufficiently cool to behave rigidly, the flow pattern is restricted within the asthenosphere, which exhibits a fluid-like behavior on geologic time scales.

This process brings upward to the base of the lithosphere some asthenospheric mantle, which is hotter than the temperature usually considered to define the lower boundary of the lithosphere, that is about $1300^{\circ} \mathrm{C}$. If such a process takes place over a sufficient time span, thinning of the lithospheric mantle by thermal erosion may occur, leading to volcanism and uplift by isostatic adjustment, in a way similar to active rifting (fig. 3 ).

Again, when the lithospheric thickening is asymmetric, the resulting flow pattern is also strongly asymmetric and 
the ascent of the asthenosphere occurs on one flank of the collision zone only, as shown by numerical simulations [Channel and Mareschal, 1989] (fig. 3).

\section{THE MODEL}

It has been shown that the formation of a mountain chain may have important mechanical consecpuences in the surrounding lithosphere [Fleitout, 1984; Channel and Mareschal, 1989]. Two different processes may result firom the creation of a lithospheric root: lithospheric extension and thermal erosion along the base of the lithosphere.

It is doubtful that these two processes are simultaneous. Once the process of the formation of the lithospheric root is on the way, a downward gravitational body force acts on the descending slab. This induces immediate extensional stresses in the adjacent lithosphere, which may eventually overcome its strength and produce whole-lithosphere failure.

By contrast, thermal erosion of the adjacent lithosphere should be a late process for two different reasons. Firstly, the lithospheric root must reach a certain depth to induce significant asthenospheric flow. As shown from numerical modelling [Channell and Mareschal, 1989], the amplitude of this flow is directly proportional to the volume of the asthenosphere replaced by mantle lithosphere. Secondly, as a thermal effect, it needs time for the hot asthenosphere brought up to the base of the lithosphere to induce thermal erosion. As a result, the passive rifting recorded in the adjacent lithosphere should predate the active rifting due to the asthenospheric flow.

We propose to solve the tectonic paradox described in the Massif Central area by taking into account the mechanical decoupling between the crust and the mantle during the formation of the Alpine chain. In the Alps, such a process certainly occurred as demonstrated by geophysical data which reveal a deep mantle lithospheric root over $220 \mathrm{~km}$ thick [e.g. Panza and Mueller, 1979; Spakman, 1986; Mueller and Panza, 1986; Babuska el al., 1990]. This corresponds to the Alpine "verschluckungszone" defined by Laubscher in 1971. The root is in marked contrast with the LAB depth of about $90-100 \mathrm{~km}$ to the west of the Sillon Houiller, a stable domain since the Hercynian orogeny which was not-affected by the rifting event [Lucazeau et al., 1984; Sobolev el al., 1996].

As expected in the process under consideration, the rifting event in the Massif Central resulting from the formation of the Alps is two-fold. It initially resembles passive rifting and is followed a few millions years later by a second stage which mimics the first stage of an active rifting.

According to geochronological data on high pressure terranes in the Alps, crustal thickening started in the middle Eocene. It appears that the lithospheric root could have been deep enough to generate extension at the time when the Frontal Penninic thrust developped (i.e. end of Priabonian or beginning of Rupelian). Then, the time available to create a significant lithospheric root capable of generating extension in the adjacent lithosphere would be about $20 \mathrm{Ma}$, from the middle Eocene to the end of the Eocene. The resulting effect in the Massif Central area is the formation of grabens at sea level which lack volcanism (fig. 4a). Stretching of the lithosphere took place over
$10 \mathrm{Ma}$ until the end of the Oligocene. From the upper Oligocene, decompression partial melting occurred in the zones of greatest lithospheric thinning (i.e. below the Limagne graben). This scattered volcanism lasted about 15 Ma up to the Upper Miocene. We consider that this first event of passive rifting ends in the Upper Miocene with the end of volcanic activity.

The flow pattern in the asthenosphere due to the creation of the lithospheric root in the Alps induces thermal erosion along the base of the adjacent lithosphere in the south of the Massif Central about $15 \mathrm{Ma}$ after the end of the

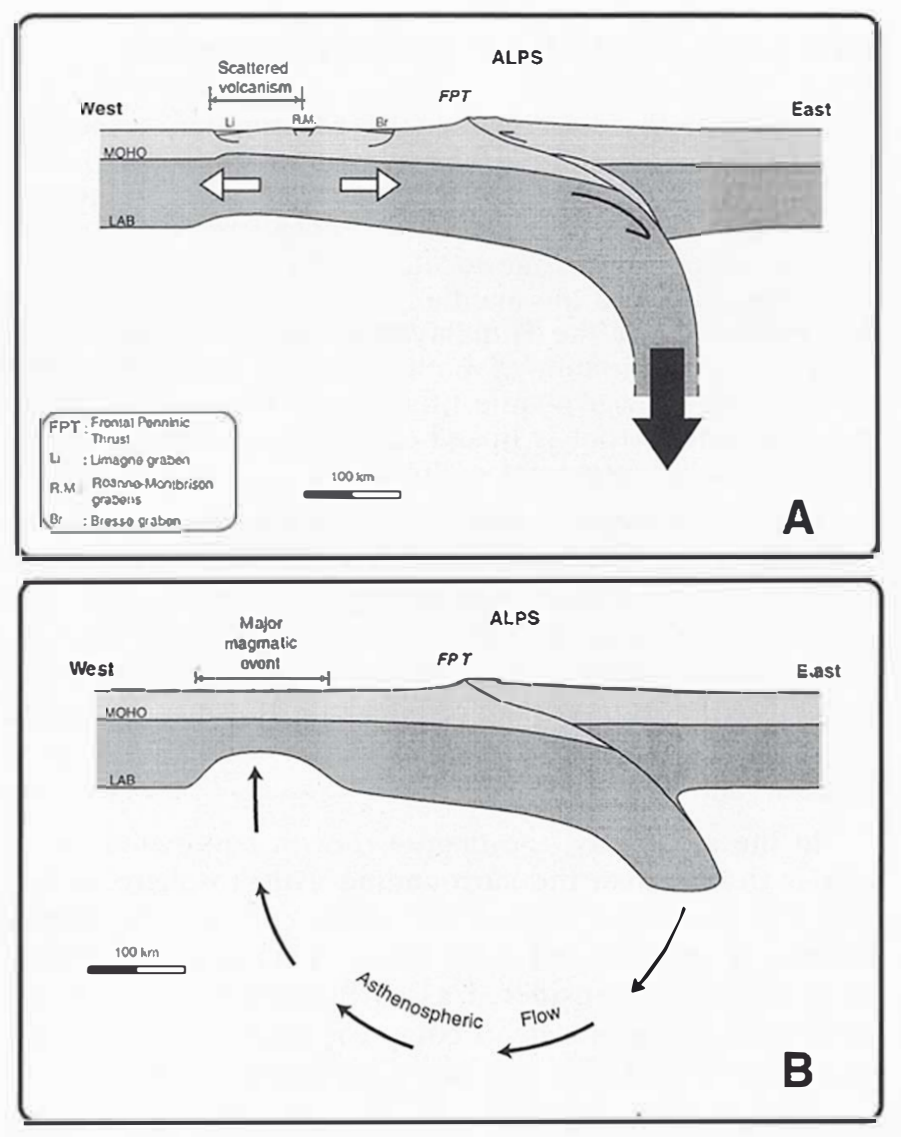

Fici. 4. - The two-fold evolution of the rifting event in the Massif Central area as explained by the deep lithospheric root of the Alps. A) The formation of the lithospheric root in Eocene-Oligocene time has induced extension in the Massil Central, which started by sedimentation at sea level followed by scattered volcanism in the late Oligocene and lower Miocene. At that time, the root is supposed to be deeper and steeper than nowadays as it is coeval with subduction of crustal slices (UHP and HP metamorphism), which werc exhumed later and outcrop now at the surface. Thermal erosion of this root may also be assumed since the (Oligocene B) The formation of the lithospheric root has induced a mantle how, which resulted in thermal erosion at the base of the lithosphere trigerring volcanism and uplift of the whole area from the Upper Miocene to the present-day (further explanation in the text).

Fig. 4.- Double évolution de lépisode de riffing dans le Massif central lice à la crécation de la profonde racine hithospherique des Alpes. A) La formation de la racine lithosphererique à l'Eo-Oligociene a induit de l'extension dans le Massif central. qui s'est d'abord manifestée par ane sédimenation au niveau de la mer: puis par une phase de voleanisme disperse a

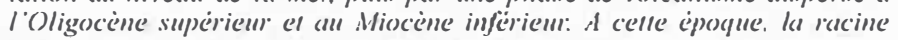
ètait probablement plus profonde qu actuellement et ècait associce à une subduction crinstale. comme le montre le meitamorphisime de ultra-haure pression dans les unitess crustales les plus internes de la chaine. B) La formation de la racine lithosphierique a induit mu flux asthemosphierique sous le Massif central qui a pour effer une erosion ihermique de la lishospliere et le developperment de la phase volcanique majeare contemporaine diune surrection du Miociene superieur à l'actunel (ef explications dans le texte). 
sedimentation period. This thermal erosion was accompanied by intense volcanism and uplift of the whole area (fig. 4b). This second event of active rifting propagated to the north of the Massif Central generating a renewal of volcanism after an interruption of about $6 \mathrm{Ma}$. As expected, this second phase of volcanism in the north is unrelated to previous zones of crustal stretching and mainly occurred in zones of normal crustal thickness (fig. 4b).

The question arises as to why the active rifting event started earlier in the south than in the north of the Massif Central and was significantly less developed in the north. Furthermore, to generate the second stage of magmatism, it is necessary to produce a thermal anomaly in the upper mantle of about $200^{\circ} \mathrm{C}$ [Granet et al., 1995b; Sobolev et al., 1996]. This requires that the lithospheric root triggers an upwelling from a deep thermal boundary layer in the upper mantle. We feel that the answer to these questions needs further studies of the flow pattern associated with the sinking of a lithospheric root. Such an understanding of the deep processes involved during the creation of a lithospheric root might be achieved by the means of numerical and analogue modelling.

It has been stressed in a companion paper [Michon and Merle, 2001] that the sedimentary and magmatic evolution of the Eger graben is surprinsingly similar to that recorded in the Massif Central. This is hardly a coincidence. When looking at a map of the depth of the lithospheric root in the
Alps (fig. 5), it appears that the Alpine root is strongly nonlinear. This may explain the three major segments of the West European rift, which are linked by large scale transform zones (i.e. The Rhin-Saône and Franconie transform zones). Likewise, reactivation of Variscan faults may explain the slight deviation of these grabens from perfect parallelism around the Alpine belt.

\section{CONCLUDING REMARKS}

From our study of the Massif Central area, we conclude that the West European Rift system may result from the coeval formation of the deep lithospheric root in the Alpine chain. Such a process would induce a two-stage rifting event in the adjacent lithosphere, as shown in the Massif Central area and the Eger graben. The first stage resembles passive rifting whereas the second stage mimics the beginning of an active rifting. This hypothesis explains most data gathered from the north and the south of the Massif Central area. Further studies on the deep structure of the Rhine graben and the Eger graben should show if the similar temporal evolution of graben formation, sedimentation and volcanism recorded in these areas can be attributed to the same overall tectonic process.

Acknowledgments. - The authors want to thank Olivier Lacombe, Jean-Christophe Maurin and Marjoric Wilson for their critical reviews.

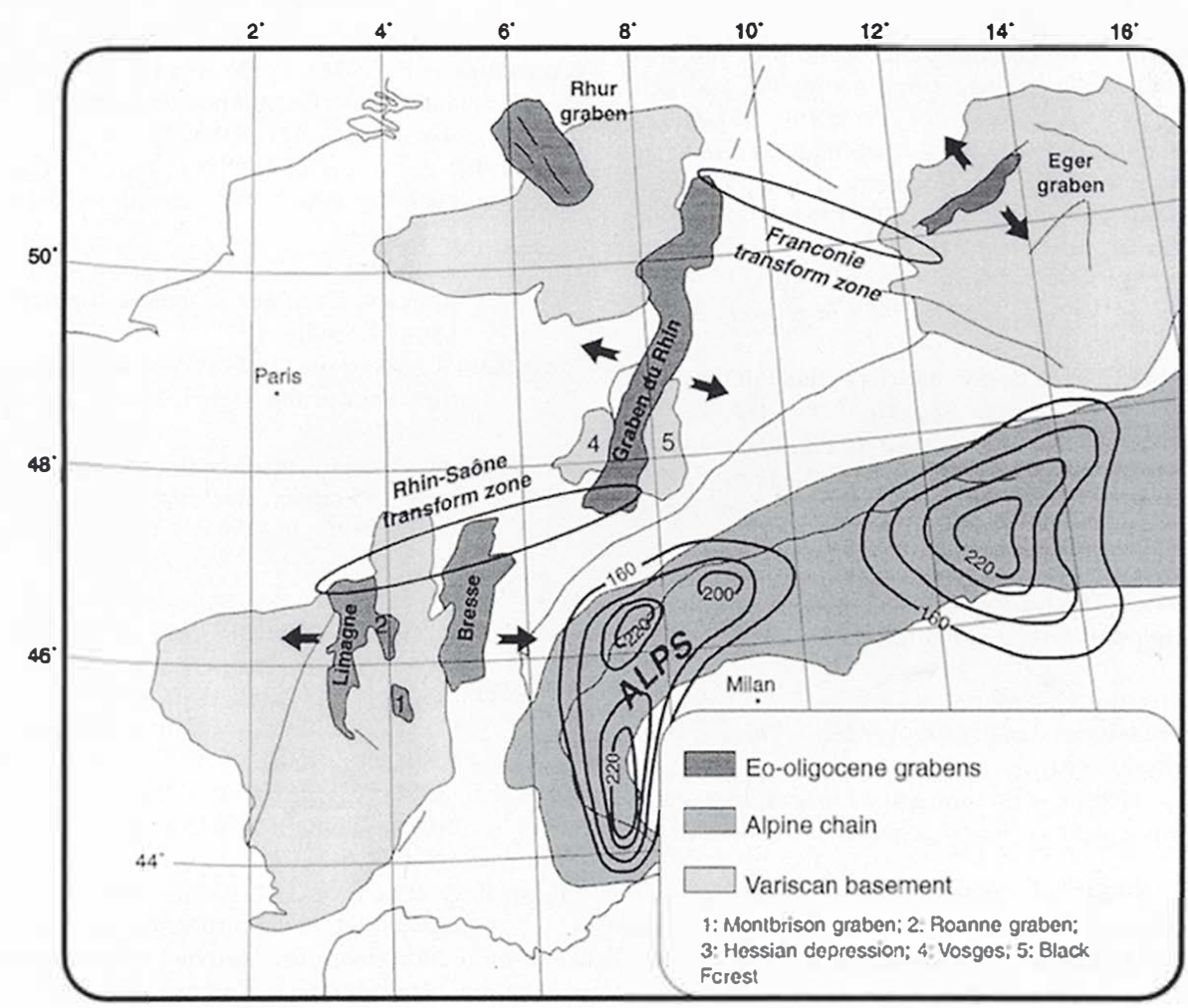

FI(i. 5. - Depth to the thermal lithosphere-asthenosphere boundary beneath the Alps showing the localisation of the deep lithospheric root with respect t) the three main segments of the West European Rifi (depth of the lithosphere-asthenosphere boundary after Babuska et al. [1990]).

FIG. 5. - Carle de la profondeur du LAB dans les Alpes montrant la position de la profonde racine lithospherique par rapport ant trois segments principanx du Rifi Ouest-europeen (profondenr de la racine lithospherrigue d'après Babuska et al. [1990]). 


\section{References}

Babuska V., Plomirova J. \& (iranet m. (1990). - The deep lithosphere in the Alps : a model inferred from P residuals. - Tectomophysics. 176. 137-165.

BARPATY J.C.. TRICART P. \& II:UI)Y De (iRISSAC (. (1992). - La quatrieme écaille pres de Briançon (Alpes trançaises): un olithostrome precurseur de l'orogenise pennique Focene. - C. R. Acest. Sci.. Paris. 314, $71-76$.

BI:RGilRAT F. (1985). - Deformations cassantes et champs de contraintes tertiaires dans la plate-lorme europecenne. - These d'etat, univ. P. et M. Curic, $315 \mathrm{p}$.

Bergerat F, Mugnier Jl., (iuellec S., Truhiert C., Cazes M., Damotte B. \& ROURE F. (1990). - Extensional tectonics and subsidence of the Bresse basin: an interpretation from ECORS data. Mim. Soc. géol. Fr: 156, 145-156.

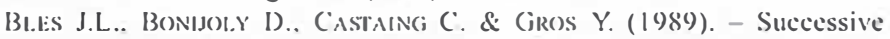
post-Variscan stress fields in the French Massil" (entral and its borders (Western European plate) : comparison will geody'namic data. - Tectomophysics, 169. 79-111.

Bodergat A.M.. Brior D., hugueney M., Poidinin J.L.. Picot L., (ilraud F., Berger J.P., Levy A. \& polgnant A. (1999). Incursions marines dans l'environnement lacustre du rift oligocène de Limagne (Massil" central. France) : apport des organismes halophiles et des isotopes du strontium; datation par les mammifërcs. - Bull. Soc: géol. Fi:. 170. 499-511.

BOwTi:. S.A. (LIFF R.A. \& BARNICOAT A.C. (1994). - Sm-Nd isotopic evidence on the age of the eclogitisation in the Zermatt-Saas ophiolites. - . Metemorph. Geol., 12, 187-196.

BRAVARD C.. KI:RCKHOVI: C. \& BARBILR R. (1981). - Rëinterpretation du sommet de la série des aiguilles d'Arves et de ses rapports avec la \%one subriançonnaise dans la vallée de l'Arc. $-C$. R. Acesd. Sci.. Paris, 292, 531-534.

BRIOT D. \& POIDEviN J.L. (1998). - Stratigraphie ${ }^{87} \mathrm{Sr} /{ }^{86} \mathrm{Sr}$ de quelques laminites carbonaties du Rupélien superieur du fossé de Limagne : incursions marines dans le rifi du Massil central français. - C. R. Acud. Sci.. Paris. 326. 479-483

CARMINATI E., WORTIL. M.I.R.. SPAKMAN W. \& SABADINI R. (1998). - The role of slab detachment processes in the opening of the western-central Meditcrancan basins: some geological and geophysical evidence. - Earth Plemes. Sci. I.ell., 160, 65)-665.

(HANNAL. J.E. \& MARI:SCHA. J.C. (1989). - Delamination and asymmetric lithospheric thickening in the development of the Tyrrhenian Rilt. In : M.P. COWARI). D. DII:TRICH \& R.(j. PARK. Eds.. Alpine tectonics. - Geol. Sos: Lond. Sp. Pub., 45, 285-302.

Chauvi: P. Enay R., Fiuck P. \& Sittlek C. (1980). - L'Est de ha France (Vosges, fosse rheinan. Bresse, Jura). - 260 Cong. Giel. Intern. Paris. 3-81.

DANGiliARI L. ( 1933 ). - Sur la presence de foraminil̈̈res dans l'(Oligocéne du Massif central. - C. R. Somm. Soc. Ciéol. Fr: 1-2, 12-13.

DIFINI: E. \& CANTAGirl: J.M. (1998). - Chronologie de l'encaissement du reseau hydrographique en domaine volcanise : lexemple de la haute vallec de la Loire. - INQLA C'OT/UISPP 31 lnser-congress Symposium. Brives-Charensac, 12-17.

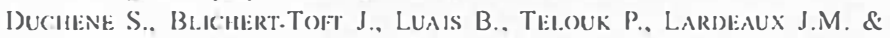
AI.13,ARI:I)L: F. (1997). - The Lu-HI dating of garnets and the ages of the Alpine high-pressure metamorphism. - Narure, 387. $586-589$.

Ft.tirout L. (1984). - Modélisation des contraintes tectoniques et des instabilites thermomecaniques dans la lithosphere. - These d Fiat. Liniv: Paris-Sucl. Paris. 433p.

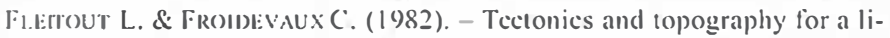
thosphere containing density heterogencities. - Tecronics. I. $21-56$.

liroTt\%HLiM N., S(HMII) S.M. \& FRI:Y M. (1996). - Mesozoic paleogeography and the timing of eclogite-lacies metamorphism in the Alps : A working hypothesis. - Eclogese geol. Heli. 89. $81-110$.

Gi:Rrbi: M.C.. (iONORI) H. \& ARNAUI) N. (1998). - Age miocene des formalions de bordure du losse du Fore\% (Massil central). - Giel. Fr:. 2. $47-53$.

(irr,UI) J. (1902). - Eludes géologiques sur la Limagne (Auvergne). These d'Elat, Ed. Ch. Beranger, Paris, $410 p$.

(iol:R de HI:RVI: A. \& ETIENNI: R. (|99)1). - Le contact Margeride Cezallier Cantal. les incidences de la lectonique el du volcanisme sur la sédimentation et I'hydrographic. - Bull. Labo. Rhod. Gieom.. 27-28. 3-21.

(iorin (i. (1974). - Etude palynostratigraphique de sédiments paléogénes de la grande Limagne (Massil eentral. France). - These $3^{\circ}$ cycle. (ienive, 314 p.

(iranlt M., Stoll. (i., Dorli. J., Achaulir U., Polpinet (i. \& Fuchs K. (1995a). - Massil Central (France) : new constraints on the geodynamical evolution from telescismic tomography. - Geophly:s. J. Int. 121, 1. 33-48.

(irAnet M., WILSON M. \& ACHAUER U. (1995b). - lmaging a mantle plume beneath the French massif Central. - Earth Planet. Sci. Letr., 136, 281-296.

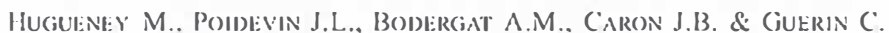
(1999). - Des mammirëres de l'Aquitanien infëricur à la Roche blanche-(iergovic (Puy de Dóme, France), revelateur de l'activite post-oligocence du rift en Limagne de Clermont. $-C: R$. Acud. Sci.. Paris. 328. 847-852.

Kl:RCKIIOVl: (:. (1969). - La zone du hy'sch dans les nappes de l'Embrunais-Ubaye. - Gielol. Alpince, 45, 5-204.

Kerckihovi: ( $(1980)$. - Panorama des séries synorogéniques des Alpes occidentales. In: A. AUTrAN \& J. Di:RCOURT. Eds.. Evolutions géologiques de la France. $26^{\circ}$ congr: géol. int., colloque (7. Weim. BRC:Y. 107, 241.

Ki:RCKIIOVI: C. \& PAIRIS J.L. (1986). - Dynamique des dépots nummulitiques marins dans les \%ones alpines internes: lexemple du Fly'sch subbriançonnais de Saint Clement (nappes de l'Embrunais-Ubaye, haut-Embrunais. Alpes occidentales lirançaise). C. R. Accul. Sci.. Paris. 303, 1227-1232.

KUSZNIR N..I. \& PARK R.(i. (1986). - The extensional strength of the continental lithosphere: its dependance on geothermal gradient and crustal composition and thickness. In: M.P. (OWARI). J.F. DI:Wl:Y \& P.L. HANCoCk, Eds., Continental extensional tectonics. - Geol. Soc. Lomd. Sp. Publ. 28. 35-52.

Lacombie O.. Angelier J., BYrni: I). \& IDUPin J.M. (1993). - Eocene-()ligocene tectonies and kinematics of the Rhine-Saone continental transform \%one (castern France). - Tectonics. 12. 874-888.

LAUBsC(IIIR H.P. (1971). - The large scale kinematics of the western Alps and the northern Apennincs and its palinspatic implications. Am. J. Sci., 271, 193-226

LEFORT J.P. \& AGARWAI. B.N.P. (1996). - Ciravity evidence for Alpine buckling of the crust beneath the Paris Basin. - Tectomophysics, 258. $1-14$.

Ll: (iruli. A. (1988). - L'evolution gémorphologique du Massif Cintral lrançais. Essai sur la geenése d'un relief. - Thèse d'état. Univ. Lyon II, 768p.

LUCAzian F., VAsSeUr (j. \& BAYliR R. (1984). - Interpretation of heat how data in the French Massif central. - Tecronophysics. 103. (9)-119.

MATTAUI:R M. (1986). - Intracontincntal subduction. crust mantle decollement and crustal stacking wedge in the Himalaya and other collision belts. In: M.P. (OW, \& \& A.C. RIl:s. Eds., Collision tectonics. - Geol. Soc. L.ond. Sp. Publ.. 19,37-50.

MCKl:NzIE D). (1978). - Active tectonics of the Alpine-Himalayan belt: The Aegean sea and surrounding regions. - Geophlys. .J. Royal Ast: Soc., 55, 217-254.

Merte: O., Michon L., CAMus (i. \& id: (iOl:R A. (1998). - L'extension oligocene sur la transversale septentrionale du rili du Massil' ('entral. - Bull. Soc. gecol. Fi:. 169. 615-626.

Michon L. \& MI:RI.I: (). (2001). - The evolution of the Massif Central rift Spatio-temporal distribution of the volcanism. - Bull. Soc. géol. [r. 172, 2. 201-211.

MonII: P. \& PhIt.IPpor P. (1989). - Mise en évidence de läge Eocéne moyen du metamorphisme de haule-pression dans la nappe ophiolitique du Monviso (Alpes oceidentales) par la méthode ${ }^{30)} \mathrm{Ar}{ }^{+10} \mathrm{Ar}$. - C. R. Accel. Sci.. Paris, 309. 245-251.

MUtil.tik S. \& PANzA (i.F. (1986). - Evidence of a deep reaching lithosphere root under the $A$ lpine are. - Ferra (ognira, 6. p.579).

PANkA (j.F. \& MUILL.LIR S. (1979). - The plate boundary between Eurasia and Africa in the Aipine area. - Mem. Sci. Geol. 33, 43-50.

PARK R.(i. (1988). - (icological structures and moving plates. - Blackic \& Son Lid. Bishopbriggs, (ilasgow, 337p. 
Rat P. (1984). - Une approche de l'environnement structural et morphologique du Pliocene el du Quaternaire bressan. - Géol. Fi. 3. 185.196.

Rl:Y R. (1973). - Biostratigraphie des formations sédimentaires du Cantal. - Rev. Scient. Bourbonnais, Moulins, 77-128.

RUBATtO D.. (jlibaUt:R D). \& FanNing M. (1998). - Jurassic formation and Eocene subduction of the Zcrmatt-Saas-Fec ophiolites: implieations for the geodynamics evolution of the central and Western Alps. - Comnrib. Mineral. Perrol., 132, 269-287.

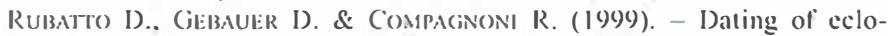
gite-facies zircons: the age of Alpine metamorphism in the Sesia-Lanzo zone (western Alps). - Earth Planet. Sci. Letl. 167. $141-158$.

SHRANNE M. (1999). - The Gulf of Lion continental margin (NW Mediterranean) revisited by IBS: an overview. In: B. DURAND, L. Jol.tvit, F. Horavat \& M. SEranne, Eds., The Mediterranean basins: Tertiary extension within the Alpine orogen. - Ceel. Soc. lond. Sp. P'ubl., 156. 15-36.

SI:RANNI: M. \& MLRLI: (). (I999). - C'enozoic rift-basins of western Europe. - Colloque (jéoFrance 3D: Résultats et Perspectives. 23-24 Novembre 1999. - Doc. BRGM, 293, 112-115.

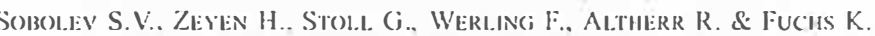
(1996). - Upper mantle temperature from teleseismic tomography of French Massif (entral including effects of composition. mineral reactions, anharmonicity, anclasticity and partial melt. - Earth Planer. Sci. Lell. 139. 147-163.

SPAKMAN WV. (1986). - The upper mantle structure in the central European-Mediterrancan region. In: R. FrlikMAN, S. Mulit.lik \& P. (intsil. Eds., Third EGT Workshop - The central segment. - European Science Foundation (Strasbourg, France). 215-221.
TILTON (j.R., SCHREYHR WV. \& SCHERTI. H.P. (1991). - Pb-Sr-Nd istopic behaviour of deeply subducted rocks from the Dora Maira massif. Western Alps, Italy-II : What is the age of the ultrahigh pressure metamorphism? - Comirib. Mineral. Petrol., 108. 22-33.

TRICART P. (1986) - Le chevauchement de la zone briançonnaise au sud-est du Pelvoux : cle des rapports \%one externe/\%one internes dans les Alpes occidentale. - Bull. Soc. géol. Fi:. (8), 2. 233-244.

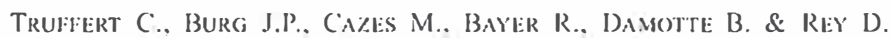
(1990). - Structures crustales sous le Jura et la Bresse: contraintes sismiques et gravimeitriques le long des prolils ECORS Bresse-Jura et Alpes II. - Wém. Soc. géol. Fi:. 156. 157-164.

TURCOTTL D).L. \& SCHUizert (j. (1982). - (icodynamics. Application of continuum physics to geological problems. - John Wiley. Chichester. 450p.

TURl.AND M. MARTlia P.. JOUVAl. J. \& MONCIARDINI ('h. (1994). - Découverte d'un épisode marin oligocène dans la série paléogène lacustre à nuviatile du bassin du Puy en Velay. - Ciéol. Fr: 4. 63-66.

VINCLNT P.M., AUBBER M., BOIVIN P, CANTAGRLL J.M. \& LINAT J.F. (1977). - Dicouverte d'un volcanisme paliocence en Auvergne: les maars de Menat el leurs annexes: ćtudes géologique el géodésique. - Bull. Soc. géol. Fi:, 5. 1057-1070.

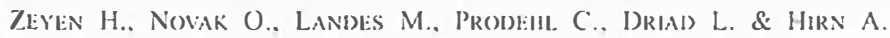
(1997). - Refaction-scismic investigations of the northern Massif ('entral (France). - Tecomophnsics, 275. 99-117.

Zilicili:R P.A. (1992), - European (eno\%oic rift system. In : P.A. Ziegiler (Eds) Geodynamics of rifting. Volume 1. Case history studies on rifis: Europe and Asia. - Techomophysics, 208. 91-111. 